\title{
IT PROJECT MANAGER COMPETENCIES AND TEAM COMMITMENT: A NEW SCALE PROPOSAL
}

\begin{abstract}
Project managers are required to develop competencies that will help them to lead their teams in stressful, challenging and dynamic environments such as in many Information Technology (IT) project settings. Project managers should also develop team commitment in order to improve team performance. Therefore, this study addresses the question: Which IT project manager competencies influence team commitment? The main objective is to develop and validate a new instrument to measure project manager competencies and team commitment in IT projects. To accomplish this objective, we, firstly, did an exploratory and qualitative research. Then, we did a quantitative research in which we collected 484 responses. Besides providing a new scale, this research also presents pertinent implications to the practice of project management in IT settings. For instance, organizations can use the measuring instrument to evaluate project managers, to evaluate the work environment as well as to structure training programs for their employees.
\end{abstract}

Keywords: Team Commitment. Organizational Commitment. Project Manager Competencies. Scale Development. Structural Equation Modeling.

\section{AS COMPETÊNCIAS DO GERENTE DE PROJETOS DE TI E COMPROMETIMENTO DE EQUIPE: PROPOSTA DE UMA NOVA ESCALA}

\section{RESUMO}

Gerentes de projetos precisam desenvolver competências necessárias para gerenciar equipes em ambientes estressantes, desafiadores e dinâmicos como costumam ser os ambientes de TI. Gerentes de projetos também precisam desenvolver o comprometimento da equipe a fim de melhorar a performance de suas equipes. Porém, construir o comprometimento de equipe não é uma tarefa fácil. Por isso, este estudo endereça a seguinte questão: quais competências do gerente de projetos de Tecnologia da Informação (TI) influenciam o comprometimento da equipe? O principal objetivo é o de desenvolver e validar um novo instrumento para medir as competências do gerente de projetos e o comprometimento da equipe em ambientes de TI. Para cumprir este objetivo, nós, primeiramente, conduzimos uma pesquisa qualitativa e exploratória. Na sequência, nós conduzimos uma pesquisa quantitativa em que coletamos 484 respostas. Além de contribuir com uma nova escala, esta pesquisa apresenta implicações pertinentes para a prática da gestão de projetos de TI. Inclusive, as empresas podem utilizar este novo instrumento para avaliar gerentes de projetos, para mensurar o ambiente de trabalho de suas equipes, como também para estruturar treinamentos corporativos.

Palavras-chave: Comprometimento de Equipe. Comprometimento Organizacional. Competências do Gerente de Projetos. Desenvolvimento de Escala. Modelagem de Equações Estruturais.

Cintia Cristina Silva de Araújo ${ }^{1}$ Cristiane Drebes Pedron ${ }^{2}$ Filipe Quevedo Pires de Oliveira e Silva ${ }^{3}$

\footnotetext{
${ }^{1} \mathrm{PhD}$ in Business Administration from Universidade Nove de Julho - UNINOVE. Brazil. E-mail: cintyaraujo@gmail.com

${ }^{2} \mathrm{PhD}$ in Management from the Technical University of Lisbon - Higher Institute of Economics and Management, Portugal. Professor at the Universidade Nove de Julho - UNINOVE. Brazil. E-mail: cdpedron@uni9.pro.br

${ }^{3} \mathrm{PhD}$ in Business Administration from Universidade Nove de Julho - UNINOVE. Professor at the Universidade Federal de Mato Grosso do Sul - UFMS. Brazil. E-mail: quevedo.silva@ufms.br
} 


\section{INTRODUCTION}

Human aspects such as lack of end user involvement, miscommunication, weak leadership and unskillful resources are appointed as causes of Information Technology (IT) project failure (The Standish Group, 2013, 2014; Sumner, Bock, \& Giamartino, 2006). IT projects with managers who have the "right competencies" and who know how to lead teams towards the project goals is crucial to ensure that the organization's projects will achieve the expected performance (Jha \& Iyer, 2007; Thamhain, 2013; Wateridge, 1997).

Unfortunately, project managers are usually promoted to this position due to their technical skills rather than their managerial skills (Kerzner, 2009; Wateridge, 1997). For this reason, many projects fail since project managers lack important skills such as communication and leadership (Kerzner, 2009; Müller \& Turner, 2010; Sumner, Bock, \& Giamartino, 2006; Turner \& Müller, 2005; Wateridge, 1997).

Altogether, IT project managers are required to develop competencies that will help them to lead their teams in stressful, challenging and dynamic environments such as in many IT project settings (Sumner et al., 2006). In fact, effective IT project managers do not lean on "technical expertise alone" to be effective (Kerzner, 2009, p. 149). IT project managers need to know how to maximize team performance and how to get the team committed with the project goals (Thamhain, 2011; 2013).

Commitment is another important component in IT project management (Jha \& Iyer, 2007). Scholars have demonstrated that team commitment positively affects team performance (Bishop, Scott, \& Burroughs, 2000) and IT project success (Xu, Zhang, \& Barkhi, 2010). However, it is known that building commitment is a very difficult task to accomplish (Thamhain, 2013). Team commitment is defined as an individual's identification and involvement with a specific team (Porter, Crampon, \& Smith, 1972). Organizational commitment can be characterized by three factors: (1) a strong belief in and acceptance of the team's goals and values, (2) a willingness to exert considerable effort on behalf of the team and (3) a strong desire to remain in the team (Bishop \& Scott, 2000; Bishop, Scott, \& Burroughs, 2000).

Surely, managerial competencies solely are not sufficient to build team commitment in organizational settings (Jha \& Iyer, 2007; Thamhain, 2013). However, as the PMI (2013, p. 17) affirms, "the project manager is the link between the strategy and the team". Therefore, IT project managers can use specific competencies to get their team members committed (Leung, Chen, \& Yu, 2008; Thamhain, 2013). In spite of all these evidences regarding the influence of project managers on team commitment, there have been few studies on the relationship between project manager's competencies and team commitment (Jha \& Iyer, 2007; Korzaan, 2009). In fact, Brazilian studies have contributed little in exploratory researches on organizational commitment (Moraes, Godoi, \& Batista, 2004).

Based on these arguments, this research project aimed to answer the following question: Which IT project manager competencies influence team commitment? To answer this question, the main objective of this study was to develop and validate an instrument to measure IT project manager competencies and team commitment.

The research was divided into two phases. In the first phase, we did an exploratory qualitative research in which sixteen semi-structured in-depth interviews were conducted with IT project managers. The second phase aimed to design a new scale on IT project manager competencies. To validate the scale, we collected 484 responses from Brazilian IT professionals.

This paper is structured as follows: introduction, theoretical background, research methodology, qualitative data analysis, quantitative data analysis, and final considerations.

\section{LITERATURE REVIEW}

In this session, we briefly present the theoretical foundations of this research.

\subsection{IT Project Manager Competencies}

The definition of competence has been the object of constant debates and remains of diffuse matter in the organizational literature (Crawford, 2005). For the purpose of this research, competence is defined as a combined set of an individual's knowledge, abilities and personal characteristics used to perform an specific task or activity (Crawford, 2005; Müller \& Turner, 2010).

Many studies have been done to determine which individual/managerial competencies are essential for efficient project management (Araújo \& Pedron, 2015; Keil, Lee, \& Deng, 2013; Skulmoski \& Hartman, 2009; Takey \& Carvalho, 2015). Unfortunately, in many firms, "personnel are generally promoted to management on the basis of 
their professional or technical competence rather than their managerial ability" (Kerzner, 2009, p. 172). This practice has many negative consequences later on, as it tends to staff projects with managers insufficiently capable to perform their role.

Technical skills are not sufficient to guarantee project success (Kerzner, 2009). For instance, in order to spur team commitment soft skills such a leadership and communication are fundamental (Thamhain, 2004). To be effective, project managers should use a synergy of different competencies since they are supposed to deal with "(1) the people to be managed, (2) the task to be done, (3) the tools available, (4) the organizational structure, and (5) the organization environment" (Kerzner, 2009, p. 148).

Regarding essential competencies for IT project managers, there is a variety of studies covering this theme (Keil et al., 2013; Skulmoski \& Hartman, 2009; Stevenson \& Starkweather, 2010). Studies indicate that IT professionals lack important skills such as communication and leadership, which jeopardizes their performance (Sumner et al., 2006). These attitudinal and interpersonal competences are known as soft skills.

Keil et al. (2013) and Skulmoski and Hartman (2009) did a thorough research on IT project managers' competencies. They collected information among IT professionals to identify which competencies project managers should develop to be more effective in IT settings. Based on their study and on other researches (PMI, 2013; Stevenson \& Starkweather, 2010), we designed a list of eighty-five project manager competencies. Then, we grouped these competencies into ten categories.

\subsection{Team Commitment}

Team commitment is similar to organizational commitment since teams build goals and principles that members can accept or not (Bishop $\&$ Scott, 2000; Bishop et al., 2000). Based on the concept of organizational commitment (Mowday, Steers, \& Porter, 1979), Bishop and Scott (2000) define team commitment as (a) an individual's strong belief in, and acceptance of, team's goals and values; (b) willingness to put in considerable effort on behalf of the team and (c) intense desire to remain as a member of the team.

Bishop et al. (2005) declare that it is important to separate an individual's commitment to the organization from the commitment he/she has towards his/her teammates. An employee may be extremely committed to the team and to the organization or he/she can be committed to the team and not to the organization and even to none of them (Bishop et al., 2005).

Literature confirms that project leaders can influence team commitment (Allen \& Meyer, 1990; Shenhar \& Dvir, 2007). Effective project leaders serve as "social architects" who spur team commitment in order to increase team performance and to ensure project success (Thamhain, 2004).

In a study on multinational projects, Thamhain (2013) concluded that to drive team commitment it is necessary to have an experienced project leader who is able to gain the team's trust, respect and credibility. Some tactics to spur team commitment are scheduling regular meetings to review project objectives and to discuss problems encountered during project execution (Sabherwal \& Elam, 1995; Thamhain, 2013).

\section{METHODOLOGY}

In order to better define the constructs scope and to analyze the relationship between them, we adopted mixed methods, as recommended by Creswell and Plano-Clark (2011). The first phase of this study was exploratory and had a qualitative approach. After the literature review, we conducted 16 (sixteen) 40-50 minute in-depth interviews with Brazilian IT project managers. Table 1 presents the professional profile of the 16 interviewees.

This first stage of the research helped us (1) to define the sample of participants for the online survey to be conducted on the quantitative stage; (2) to determine which competencies would be included or excluded from the new measuring instrument; (3) to define the boundaries of the research constructs; and (4) to obtain a better understanding of IT project management on Brazilian organizations. 
Table 1 - Interviewees' profile

\begin{tabular}{|c|c|c|c|c|}
\hline Interviewee & Occupation & Firm's Business Sector & $\begin{array}{c}\text { Yrs of } \\
\text { Experience }\end{array}$ & $\begin{array}{l}\text { Size of projects } h / s \\
\text { has managed }\end{array}$ \\
\hline 1 & IT manager & $\begin{array}{l}\text { Big multinational fashion retail clothing } \\
\text { store }\end{array}$ & 20 & All sizes \\
\hline 2 & $\begin{array}{l}\text { IT project } \\
\text { manager }\end{array}$ & Small technology consultancy & 10 & Small to medium \\
\hline 3 & $\begin{array}{l}\text { IT project } \\
\text { manager }\end{array}$ & Small technology consultancy & 5 & Small to medium \\
\hline 4 & $\begin{array}{l}\text { IT project } \\
\text { manager }\end{array}$ & Big multinational IT consultancy & 20 & All sizes \\
\hline 5 & $\begin{array}{l}\text { IT project } \\
\text { manager }\end{array}$ & Big multinational technology company & 18 & All sizes \\
\hline 6 & $\begin{array}{l}\text { IT project } \\
\text { manager }\end{array}$ & Big multinational technology company & 15 & All sizes \\
\hline 7 & $\begin{array}{l}\text { IT project } \\
\text { manager }\end{array}$ & $\begin{array}{l}\text { Multinational in the telecommunication } \\
\text { sector }\end{array}$ & 16 & All sizes \\
\hline 8 & $\begin{array}{l}\text { IT project } \\
\text { manager }\end{array}$ & $\begin{array}{l}\text { Multinational in the telecommunication } \\
\text { sector }\end{array}$ & 8 & Small to medium \\
\hline 9 & $\begin{array}{l}\text { IT Business } \\
\text { Analyst }\end{array}$ & $\begin{array}{l}\text { Multinational in the telecommunication } \\
\text { sector }\end{array}$ & 5 & Small to medium \\
\hline 10 & $\begin{array}{c}\text { IT Senior } \\
\text { Business } \\
\text { Analyst }\end{array}$ & $\begin{array}{l}\text { Multinational in the telecommunication } \\
\text { sector }\end{array}$ & 7 & All sizes \\
\hline 11 & $\begin{array}{c}\text { Senior System } \\
\text { Analyst }\end{array}$ & Public data processing company & 10 & Small to medium \\
\hline 12 & $\begin{array}{l}\text { Team } \\
\text { Coordinator }\end{array}$ & Multinational e-commerce company & 16 & All sizes \\
\hline 13 & $\begin{array}{l}\text { IT Project } \\
\text { Management }\end{array}$ & $\begin{array}{l}\text { Multinational security and protection } \\
\text { company }\end{array}$ & 5 & All sizes \\
\hline 14 & $\begin{array}{l}\text { IT Project } \\
\text { Management }\end{array}$ & $\begin{array}{l}\text { Multinational security and protection } \\
\text { company }\end{array}$ & 6 & All sizes \\
\hline 15 & $\begin{array}{l}\text { IT Project } \\
\text { Management }\end{array}$ & $\begin{array}{l}\text { Multinational security and protection } \\
\text { company }\end{array}$ & 7 & All sizes \\
\hline 16 & $\begin{array}{c}\text { IT Senior } \\
\text { Business } \\
\text { Analyst }\end{array}$ & $\begin{array}{l}\text { Multinational security and protection } \\
\text { company }\end{array}$ & 10 & Small to medium \\
\hline
\end{tabular}

Source: Authors 


\section{IT Project Manager Competencies and Team Commitment: A New Scale Proposal}

After transcribing the interviews, we analyzed the collected data using the software NVIVO 10. We used codification to classify the collected data. The codes or categories were generated based on literature review as recommended by Gibbs (2008). The code categories are: IT Project Manager's Competencies and Organizational Commitment.

Based on the qualitative analysis, we defined the research constructs - IT project manager competencies and team commitment - as well as the boundaries of these constructs. We opted for studying the direct relationship between IT project manager competencies and team commitment without considering different levels of impact for each competence category, as literature shows that the project manager should combine different competences and abilities to foster team commitment and guarantee project success (Thamhain, 2004).

Figure 1 illustrates the conceptual model of research.

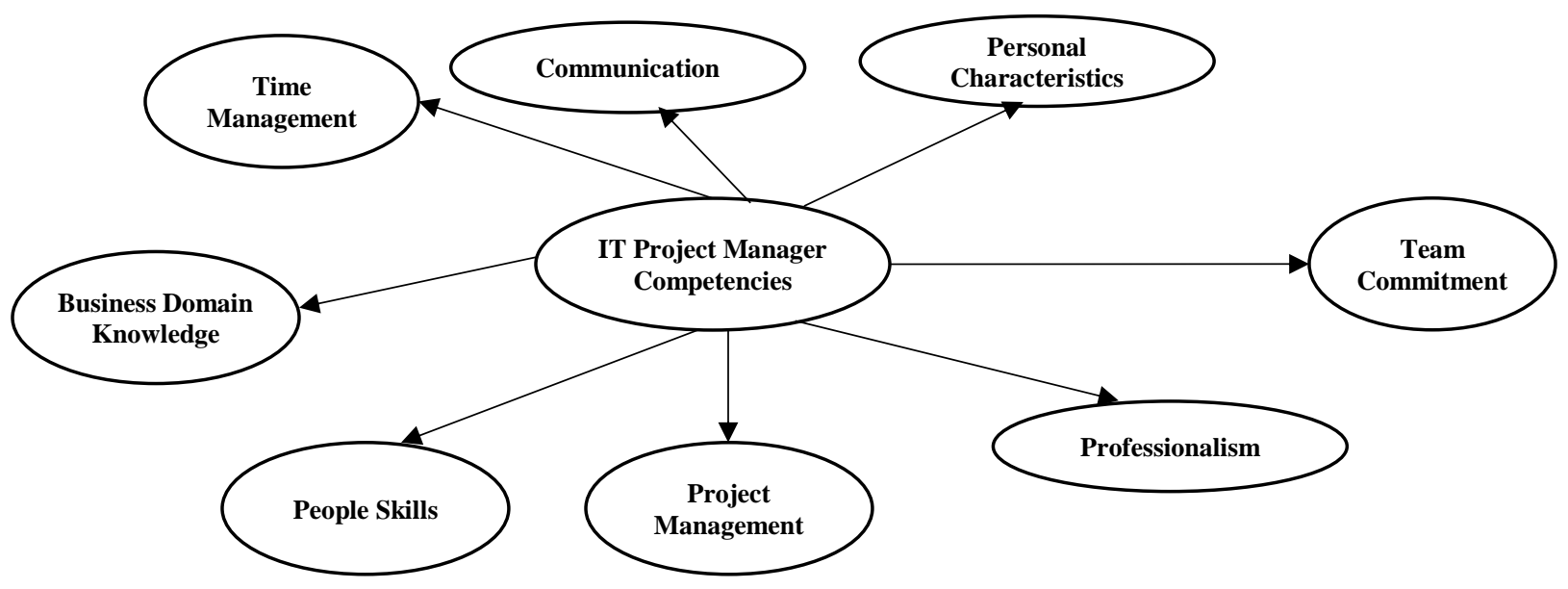

Figure 1 - Conceptual Model of the Research Constructs Source: Authors

In the second phase of the research, we conducted a quantitative research that gave us the necessary data to design an instrument to measure the IT project manager competencies that influence team commitment. The items of the new scaled were extracted from 85-competence list. To avoid excess of scale items, we kept only the most relevant competencies according to the qualitative analysis.

To design the new scale, we adopted Slavec's and Drnovesek's (2012) procedure of scale development. Founded on the classical Churchill's (1979) paper, Slavec and Drnovesek (2012) propose a ten-step procedure. These ten steps were grouped in three stages: "(1) theoretical importance and existence of the construct, (2) representativeness and appropriateness of data collection, and (3) statistical analysis and statistical evidence of the construct" (Slavec \& Drnovesek, 2012, p. 53).

In the first stage of the scale development, we focused on content domain specification, item pool generation and content validity evaluation. We defined the content domain of the new scale based on the results of the qualitative phase of the research. Then, we had six experts reviewing the scale items. Later, the questionnaire was written and revised, translation and back-translation of the questionnaire were performed, and a pilot study with nineteen people was performed as recommended by Slavec and Drnovesek (2012). Afterwards, we added eight items related to team commitment, extracted from the study of Bishop and Scott (2000). That was necessary to verify which competencies were more related to team commitment both in the exploratory and confirmatory factor analysis (Henseler, Ringle, \& Sinkovics, 2009). After performing these steps, the number of items in the scale was fifty. Appendix 1 and 2 show the scale items in Portuguese and English, respectively.

The next stage of the scale design consisted of sampling and collecting data. To apply the online survey, we used Google Forms. In the online survey, we I used a 5-point Likert-scale format that ranged from 5 (strongly agree) to 1 (strongly disagree). Before the items regarding team commitment, we added the statement "Based on what you have observed, how do team member behave in IT projects?" In turn, before the items related to IT project manager competencies, we added the statement "Based on what you have 


\section{IT Project Manager Competencies and Team Commitment: A New Scale Proposal}

observed, what are the attitude and characteristics of IT project managers?"

Our target population was Brazilian IT professionals who work in project settings. Regarding the sample size, DeVellis (2003) suggests that the sample of respondents should be high and in direct proportion to the number of items. It means that, as the number of items increases, the numbers of respondents should increase as well (Hinkin, 1998). Based on that, we decided to determine the number of responses based on researches that affirm that 200 responses are necessary for confirmatory factor analysis (CFA) and other 200 responses for exploratory factor analysis (EFA) (Guadagnoli \& Velicer, 1988; Hinkin, 1998). The period of data collection was from September to October, 2014. During this period, 484 valid responses were collected.

The last stage of scale development refers to the statistical analysis and statistical evidence of the construct. It involved three steps: dimensionality assessment, reliability assessment and construct validity assessment. We used the Exploratory Factor Analysis (EFA) to Confirmatory Factor Analysis (CFA) to perform dimensionality assessment as instructed by Slavec and Drnovesek (2012). We randomly split the sample in half: the first half was used to perform EFA and the remaining 242 responses were used in the CFA. To perform EFA, we used the software SPSS and to perform the CFA, SmartPLS.

\section{RESULTS}

Most of respondents were men, as they represented $76 \%$; only $24 \%$ of participants were women. Regarding respondents' job position, the range of participants contained all sort of IT related occupations: systems analysts, IT company owners, executives, consultants, programmers. To comply with a primary condition of the research, all respondents worked in IT project settings. In regard to IT experience of the participants of the survey, $89 \%$ had at least five years of experience.

As already mentioned, the sample was split in two so we would perform the factorial analyses with distinct samples. Following, we present the results of statistical analysis (EFA and CFA) used to assess the dimensionality of the new scale (Slavec \& Drnovesek, 2012).

\subsection{Exploratory Factor Analysis (EFA)}

The EFA is used to assess to which dimension the scale items (or indicators) should belong to (Zambaldi, Costa, \& Ponchio, 2014). In the EFA, we excluded eleven items due to their low factorial loading (less than 0.5). We also excluded item 2 was because its communality rate was below 0.5 (0.462). In total, 12 indicators were excluded in the EFA. Table 2 lists the scale items that were excluded and the criteria according to which these items were excluded.

Table 2 - List of the scale items that were excluded in the EFA

\begin{tabular}{|c|l|c|}
\hline Indicator & \multicolumn{1}{|c|}{ Item description } & Reason for exclusion \\
\hline TC2 & Accept doing almost any task to remain in the team they are working with. & $\begin{array}{c}\text { Low communality } \\
\text { loading }\end{array}$ \\
\hline PCH5 & Are organized people. & \multirow{2}{*}{ Factorial loading < 0.5} \\
\hline PCH2 & Know how to satisfy the motivations of the business and technical personnel. \\
\hline PCH3 & Take decisions based on real facts instead of feelings or personal beliefs. & \\
\hline TM8 & Delegate power and responsibilities to team members (empowerment). & \\
\hline TM6 & Engage themselves to accomplish tasks spontaneously. & Share credit for project success with their team. \\
\hline BDK7 & $\begin{array}{l}\text { Understand the cultural differences within the organization and know how to } \\
\text { deal with the "unwritten guidelines". }\end{array}$ & \\
\hline COMM5 & Listen closely to his/her team members. \\
\hline BDK6 & See the big picture and make tactical/strategic decisions that benefit the project. \\
\hline COMM2 & Know how to persuade people to follow one direction rather than the other. \\
\hline PS2 & Know how to satisfy the motivations of the business and technical personnel. & \\
\hline
\end{tabular}

Source: Authors

We checked the Barlett's Test of Sphericity and the Kaiser-Meyer-Olkin Test of Sampling Adequacy (KMO) to assess the strength of the relationship between the variables (Beavers et al.,
2013) and how suitable the data is for factor analysis (Williams, Onsman, \& Brown, , 2010). The Barlett's Test of Sphericity $(\mathrm{p}<0.001)$ and a KMO index of 
0,962 indicate that the collected data was suitable for factor analysis.

According to Hair et al. (1995 apud Williams, Onsman, \& Brown, 2010) in the humanities, the total explained variance should be at $50-60 \%$. The cumulative percentage of variance in the statistical analysis was $66.294 \%$. To assess the relationship communication and people skills were grouped in the same factor, such as indicators related to professionalism and personal characteristics. between the factors we used the orthogonal VARIMAX rotation method (Beavers et al., 2013). Table 3 presents the rotation matrix that derived from the statistical analysis. It is important to note that the indicators of IT project manager competencies were grouped differently from the original version of scale: indicators related to

Table 3 - VARIMAX rotation matrix

\begin{tabular}{|c|c|c|c|c|c|c|}
\hline \multirow{2}{*}{ Indicators } & \multicolumn{6}{|c|}{ Loadings within the six factors } \\
\hline & 1 & 2 & 3 & 4 & 5 & 6 \\
\hline PROF3 & 0.696 & & & & & \\
\hline PROF2 & 0.688 & & & & & \\
\hline PROF4 & 0.676 & & & & & \\
\hline PROF5 & 0.634 & & & & & \\
\hline PROF1 & 0.607 & & & & & \\
\hline PCH1 & 0.595 & & & & & \\
\hline PCH4 & 0.562 & & & & & \\
\hline PCH6 & 0.550 & & & & & \\
\hline PM6 & 0.544 & & & & & \\
\hline TC6 & & 0.784 & & & & \\
\hline TC8 & & 0.755 & & & & \\
\hline TC7 & & 0.755 & & & & \\
\hline TC5 & & 0.705 & & & & \\
\hline TC4 & & 0.689 & & & & \\
\hline TC3 & & 0.658 & & & & \\
\hline TC1 & & 0.648 & & & & \\
\hline TM4 & & & 0.659 & & & \\
\hline TM1 & & & 0.639 & & & \\
\hline TM7 & & & 0.583 & & & \\
\hline TM5 & & & 0.567 & & & \\
\hline TM3 & & & 0.524 & & & \\
\hline PM2 & & & & 0.731 & & \\
\hline PM4 & & & & 0.687 & & \\
\hline PM3 & & & & 0.672 & & \\
\hline BDK5 & & & & 0.617 & & \\
\hline PM5 & & & & 0.591 & & \\
\hline PM1 & & & & 0.576 & & \\
\hline PS4 & & & & & 0.688 & \\
\hline PS3 & & & & & 0.639 & \\
\hline PS1 & & & & & 0.579 & \\
\hline PS5 & & & & & 0.562 & \\
\hline COMM1 & & & & & 0.553 & \\
\hline COMM4 & & & & & 0.536 & \\
\hline COMM3 & & & & & 0.503 & \\
\hline BDK3 & & & & & & 0.732 \\
\hline BDK2 & & & & & & 0.646 \\
\hline BDK4 & & & & & & 0.518 \\
\hline BDK1 & & & & & & 0.502 \\
\hline
\end{tabular}

Source: Authors 


\subsection{Confirmatory Factor Analysis (CFA)}

As instructed by Slavec and Drnovesek (2012), the CFA was performed to assess the results of the EFA. As shown in the figure 2, the construct of IT project manager competencies was set as a construct of second order, linking the other competence categories with the construct of team commitment. Besides that, after the EFA, the model was simplified: instead of seven competence categories, the final version of the model presents five categories.

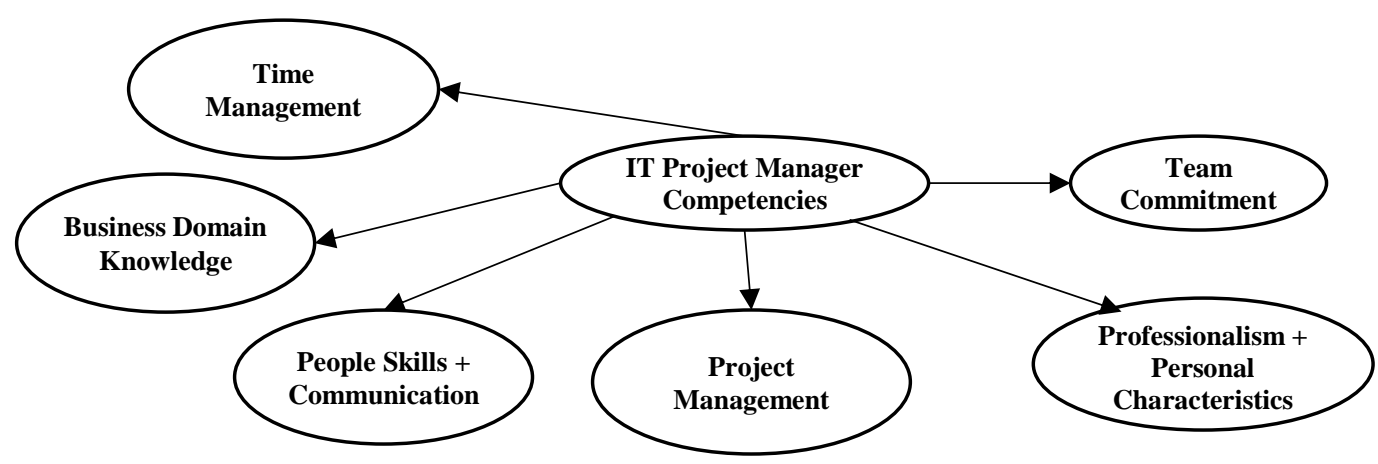

Figure 2 - The conceptual model that was tested in CFA Source: Authors

The model is reflective as the construct of IT project manager competencies causes the measurement (covariation) of the indicators (note the arrows pointing from the variable to its indicators) (Henseler et al., 2009).

To perform the CFA, we followed the instructions of Ringle, Silva, and Bido (2014). Therefore, firstly, we assessed the convergent validity (by checking the AVE of the variables), the discriminant validity and the composite reliability. To assess the discriminant validity used verified the cross loadings the Fornell-Larcker criteria. In this step, the indicator PS1 "Manage conflicts constructively to obtain alignment within those involved in the project" was excluded.

Table 4 displays the AVE (Average Variance Extracted), the composite reliability, the coefficient of determination $\left(R^{2}\right)$ and the Cronbach's alpha. As the instructed by Ringle et al. (2014), the AVE is greater than 0.50, the Cronbach's Alpha is greater than 0.70, the composite reliability is greater than 0.70 . The Pearson's determination $\left(\mathrm{R}^{2}\right)$ indicates that IT project manager competencies have a high effect on team commitment (44.61\%).

Table 4 - Results of the CFA

\begin{tabular}{|c|c|c|c|c|}
\hline Construct & AVE & $\begin{array}{c}\text { Composite } \\
\text { Reliability }\end{array}$ & $\mathbf{R}^{\mathbf{2}}$ & $\begin{array}{c}\text { Cronbach's } \\
\text { Alpha }\end{array}$ \\
\hline BUSS KNOW & 0.649388 & 0.880776 & 0.674762 & 0.819762 \\
\hline PROF+PCH & 0.638562 & 0.940577 & 0.859282 & 0.928379 \\
\hline PROJ MANAG & 0.63674 & 0.912997 & 0.745421 & 0.885426 \\
\hline PSKILLS+COMM & 0.665977 & 0.922707 & 0.792392 & 0.899243 \\
\hline TEAM COMMIT & 0.605509 & 0.914532 & 0.446089 & 0.890326 \\
\hline TEAM MANAG & 0.596921 & 0.880571 & 0.739728 & 0.829887 \\
\hline
\end{tabular}

Source: Authors

According to Fornell and Larcker (1981), the AVE of each latent variable should be higher than the square of their correlations with the other latent variables. The result of the Fornell-Larcker criterion is described in Table 5. 
Table 5 - Results of the Fornell-Larcker criterion

\begin{tabular}{|c|c|c|c|c|c|c|}
\hline & BUSS KNOW & PROF+PCH & $\begin{array}{c}\text { PROJ } \\
\text { MANAG }\end{array}$ & $\begin{array}{c}\text { PSKILLS+ } \\
\text { COMM }\end{array}$ & $\begin{array}{c}\text { TEAM } \\
\text { COMMIT }\end{array}$ & $\begin{array}{c}\text { TEAM } \\
\text { MANAG }\end{array}$ \\
\hline BUSS KNOW & 0.80585 & & & & & \\
\hline PROF+PCH & 0.705795 & 0.7991 & & & & \\
\hline PROJ MANAG & 0.69267 & 0.761576 & 0.79796 & & & \\
\hline PSKILLS+COMM & 0.734422 & 0.786084 & 0.706382 & 0.81607 & & \\
\hline TEAM COMMIT & 0.415323 & 0.546634 & 0.482959 & 0.48668 & 0.77814 & \\
\hline TEAM MANAG & 0.701584 & 0.743569 & 0.696448 & 0.751097 & 0.50713 & 0.77261 \\
\hline
\end{tabular}

Source: Authors

Note: TC is the abbreviation for Team Commitment, TM for Team Management, BDK for Business Domain Knowledge, CPK for Communication + People Skills, PM Project Management, PPC for Professionalism + Personal Characteristics

The path coefficients were assessed to evaluate the causal relations of between the constructs (Ringle et al., 2014). Figure 3 presents the final model, after the adjustment and verification performed during the CFA.

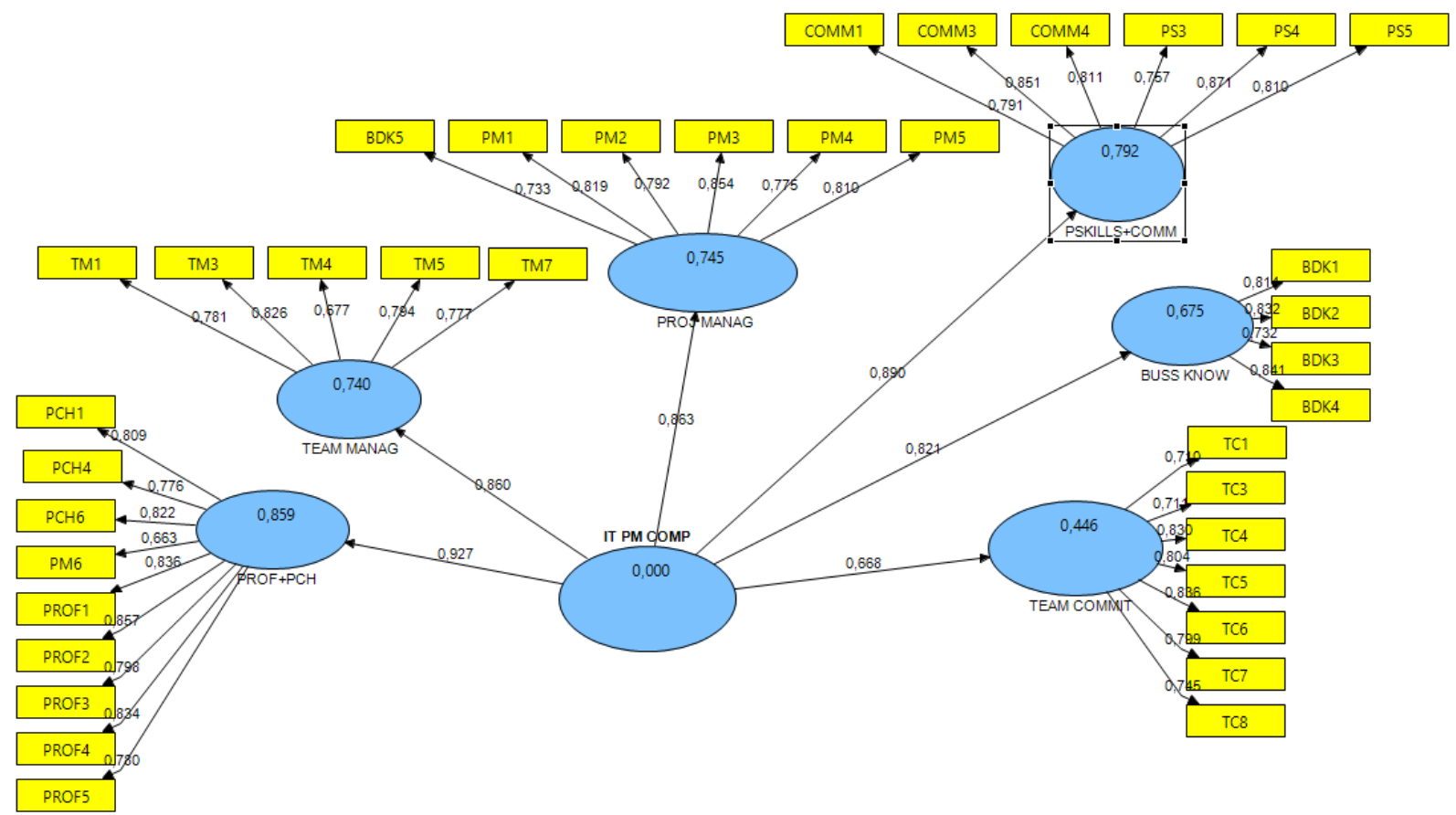

Figure 3 - Final model

Note: The numbers on the arrows represent the path coefficients (HENSELER et al., 2009)

Finally, table 6 presents the final version of the instrument, with the loadings of the indicators and the AVE of each variable. The final version of the instrument has 37 items. 
IT Project Manager Competencies and Team Commitment: A New Scale Proposal

Table 6 - Final version of the instrument with indicators' loadings and constructs' AVE

\begin{tabular}{|c|c|c|c|c|}
\hline $\begin{array}{l}\text { Construct \& } \\
\text { AVE }\end{array}$ & Indicators & Competence & Scale Item & Loadings \\
\hline \multirow{7}{*}{$\begin{array}{c}\text { Team } \\
\text { Commitment } \\
\text { AVE }=\mathbf{0 . 6 0 5 5 0 9}\end{array}$} & TC1 & \multirow{7}{*}{ Not applicable } & Think it is great working with team mates & 0.710191 \\
\hline & TC3 & & $\begin{array}{l}\text { Believe that their personal values are aligned with the values of the team they are } \\
\text { working with. }\end{array}$ & 0.710922 \\
\hline & TC4 & & Feel proud to be part of the team they are in. & 0.830243 \\
\hline & TC5 & & Feel motivated to give their best for the welfare of the team. & 0.804284 \\
\hline & TC6 & & Feel happy to be part of the team they are currently in. & 0.836315 \\
\hline & TC7 & & Indeed care about what happens to their team. & 0.798621 \\
\hline & TC8 & & Believe that the team they are in is the best place to work. & 0.745244 \\
\hline \multirow{5}{*}{$\begin{array}{c}\text { Team } \\
\text { Management } \\
\text { AVE }=\mathbf{0 . 5 9 6 9 2 1}\end{array}$} & TM1 & $\begin{array}{l}\text { Ability to motivate } \\
\text { team members }\end{array}$ & $\begin{array}{l}\text { Lead the team without being authoritarian, so that the team accomplishes the project } \\
\text { goals with enthusiasm. }\end{array}$ & 0.781006 \\
\hline & TM3 & $\begin{array}{l}\text { Ability to bridge } \\
\text { diverse teams }\end{array}$ & Have a good understanding of each team's responsibilities and where they overlap. & 0.826035 \\
\hline & TM4 & Virtual team skills & $\begin{array}{l}\text { Know how to deal with cross-cultural factors such as different time zones, international } \\
\text { customs, holidays, traditions and distinct work ethics. }\end{array}$ & 0.676567 \\
\hline & TM5 & Share information & Share information about the project with all people involved. & 0.794293 \\
\hline & TM7 & Provide feedback & Give team members timely positive or negative feedback. & 0.776954 \\
\hline \multirow{5}{*}{$\begin{array}{c}\text { Business Domain } \\
\text { Knowledge } \\
\text { AVE }=0.649388\end{array}$} & BDK1 & $\begin{array}{l}\text { Ability to understand } \\
\text { the business domain }\end{array}$ & $\begin{array}{l}\text { Understand the business requirements as well as the factors that can affect the project's } \\
\text { health instead of only focusing on the technical solution. }\end{array}$ & 0.813911 \\
\hline & BDK2 & $\begin{array}{l}\text { Ability to identify } \\
\text { stakeholders }\end{array}$ & Identify the individuals (stakeholders) that will be impacted by the project. & 0.832143 \\
\hline & BDK3 & $\begin{array}{l}\text { Ability to involve } \\
\text { end-users }\end{array}$ & Sell the project to end-users and make them accept the system. & 0.732221 \\
\hline & BDK4 & $\begin{array}{l}\text { Knowledge of the } \\
\text { end product }\end{array}$ & Understand what the end product is. How it works and what it must accomplish. & 0.840529 \\
\hline & BDK5 & $\begin{array}{l}\text { Ability to document } \\
\text { process }\end{array}$ & Document organizational processes effectively. & 0.733295 \\
\hline \multirow{5}{*}{$\begin{array}{c}\text { Project } \\
\text { Management } \\
\text { AVE }=\mathbf{0 . 6 3 6 7 4}\end{array}$} & PM1 & Scope management & Manage the project scope well. & 0.819065 \\
\hline & PM2 & Project planning & $\begin{array}{l}\text { With business requirements as a starting point. Create activities and precise deadlines. } \\
\text { Avoiding penalties for not meeting these deadlines. }\end{array}$ & 0.791766 \\
\hline & PM3 & Time management & $\begin{array}{l}\text { Make a good time management to prevent bottlenecks. by using appropriate techniques } \\
\text { such as critical path analysis. }\end{array}$ & 0.853888 \\
\hline & PM4 & Cost management & Have good control of project budget and its actual costs. & 0.774844 \\
\hline & PM5 & Risk management & Identify potential risks and develop a plan to reduce or eliminate these risks. & 0.809596 \\
\hline
\end{tabular}

ARAÚJO/ PEDRON QUEVEDO-SILVA
Revista de Gestão e Projetos - GeP

Vol. 9, N. 1. Janeiro/Abril. 2018 
IT Project Manager Competencies and Team Commitment: A New Scale Proposal

\begin{tabular}{|c|c|c|c|c|}
\hline $\begin{array}{l}\text { Construct \& } \\
\text { AVE }\end{array}$ & Indicators & Competence & Scale Item & Loadings \\
\hline \multirow{6}{*}{$\begin{array}{c}\text { People Skills } \\
+ \\
\text { Communication } \\
\text { AVE = 0.665977 }\end{array}$} & PS3 & $\begin{array}{c}\text { Political } \\
\text { awareness/agility/tact }\end{array}$ & Discern and deal with political issues. & 0.757305 \\
\hline & PS4 & Good people skills & Work with and interact with all types of people in all types of situations. & 0.870936 \\
\hline & PS5 & Negotiation & $\begin{array}{l}\text { Build relationships and are able to negotiate with the different people involved at distinct } \\
\text { hierarchical levels (technical and business area). }\end{array}$ & 0.809635 \\
\hline & COMM1 & Communication & $\begin{array}{l}\text { Have both verbal and written skills to communicate well with all those involved in the } \\
\text { project. }\end{array}$ & 0.791243 \\
\hline & COMM3 & Open communication & $\begin{array}{l}\text { Communicate openly in order to build trust and improve communication in all project } \\
\text { phases. }\end{array}$ & 0.850938 \\
\hline & COMM4 & $\begin{array}{c}\text { Ability to } \\
\text { communicate at } \\
\text { multiple levels }\end{array}$ & $\begin{array}{l}\text { Are able to communicate not only with his/her team members but also with stakeholders } \\
\text { and people from different hierarchical levels. }\end{array}$ & 0.811266 \\
\hline \multirow{9}{*}{$\begin{array}{c}\text { Professionalism + } \\
\text { Personal } \\
\text { Characteristcs } \\
\text { AVE }=\mathbf{0 . 6 3 8 5 6 2}\end{array}$} & PCH1 & Cooperation & Help others for the common benefit. & 0.809312 \\
\hline & PCH4 & Initiative-proactive & Have initiative and pro-activity. & 0.776077 \\
\hline & PCH6 & $\begin{array}{l}\text { Transparency- } \\
\text { honesty }\end{array}$ & Are transparent and honest. & 0.82196 \\
\hline & PM6 & $\begin{array}{l}\text { Identify/expand } \\
\text { opportunities }\end{array}$ & Identify and expand opportunities for improvement and growth. & 0.662758 \\
\hline & PROF1 & Credibility & Keep their promises and demonstrate a high level of ethics. & 0.836432 \\
\hline & PROF2 & $\begin{array}{l}\text { Participate and } \\
\text { contribute fully }\end{array}$ & Participate and contribute fully. & 0.856981 \\
\hline & PROF3 & Ownership of tasks & Are accountable for their tasks. & 0.797666 \\
\hline & PROF4 & Commitment & Are committed to the project. & 0.834097 \\
\hline & PROF5 & Experience & Know how to learn from past experiences and interaction with others professionals. & 0.780312 \\
\hline
\end{tabular}

Source: Authors 


\section{IT Project Manager Competencies and Team Commitment: A New Scale Proposal}

\section{DISCUSSION}

Differently from the article Keil et al. (2013), the competence categories of communication and people skills were grouped into a single one and the same occurred with the professionalism and personal characteristics. Since individuals tend to take into the organization environment their cultural identity (Hilal, 2003; Hofstede, Hofstede, \& Minkov, 2010), we can look at some aspects of Brazilian culture in order to understand this result. Brazilian culture is strongly relational (Hilal, 2003) and Brazilians have a high tendency to take things personally (Damatta, 1997). Therefore, it is understandable why our respondents did not separate communication abilities from people oriented abilities. Neither did they separate professionalism from personal characteristics.

According to the statistical analysis, communicating well with superiors and peers (items COMM1, COMM4), creating trust within project team members and stakeholders (COMM3), building relationships (PS4, PS5) and dealing with conflicts and political issues (PS3) are strongly correlated. These results indicate that how important is communication for IT project managers efficiency (Brière, Proulx, Flores, \& Laporte, et al., 2015).

In the same reasoning, ethics, credibility, accountability and commitment (PROF1, PROF2, PROF3, PROF4, PROF5), cooperation, empathy, initiative, transparency and honesty (PCH1, PCH4, PCH6) are interrelated as well as related to the ability to identify opportunities (PM6). We can also infer the influence of our relational society (Damatta, 1997) on this result. We can also infer that leaders can use specific competencies to develop a healthy work environment that can improve team's productivity and creativity, fact that has been already depicted in other studies (Araújo, Modolo, Carneiro, \& Vils, 2017;

It should be mentioned that $35.5 \%$ of respondents think that IT project managers have little or any empathy. This result may reflect a cultural characteristic of Brazilian leaders: for Hofstede et al. (2010), Brazilian business leaders tend to focus more on their own interests than on the expectations of others (i.e. stakeholders and community).

Most of the items regarding project management competencies were kept together (PM1, PM2, PM3, PM4, PM5) alongside an indicator that was originally linked to business domain knowledge (BDK5 "Document organizational processes effectively"). This result is in tune with previous studies such us Brière et al. (2015) that emphasize how fundamental are project management competencies for professionals to achieve success.
Regarding business domain knowledge it is worth mentioning that research findings are in accordance with other studies that highlight the role of project managers on aspects related to business area. Nowadays, project managers are expected to be well informed about business criteria as well as to manage the expectations from the business area (Kerzner, 2009; Rigo, Pedron, Caldeira, \& Araújo, 2016). In fact, IT project managers need to develop not only their technical competencies but also their soft skills communication, interpersonal abilities (Araújo \& Pedron, 2016).

\section{FINAL CONSIDERATIONS}

Project manager competencies and team commitment are topics that usually are presented at the literature (Stevenson \& Starkweather, 2010; Thamhain, 2013). However, we could not find a scale that would identify and measure the project manager competences that impact team commitment. Therefore, we aimed to answer the following research question: which IT project manager competencies influence team commitment? The main objective of this study was to develop and validate an instrument to measure project manager competencies and team commitment.

At the conclusion of the research, we presented a scale with five categories and thirty-seven items. The results of the statistical analysis show that the scale is very consistent and has a strong correlation with the research constructs. According to the research results, the five competence categories that impact team commitment on IT projects are business domain knowledge, communication combined with people skills, team management, project management and professionalism combined with person characteristics.

Research results are of great use for the academia and project management practice. The statistical analysis demonstrates that almost $45 \%$ of team commitment can be explained by IT project manager competencies. The implications of this finding are very relevant for the practice of project management. IT project managers should develop competencies and create ways make their teams committed to the project objectives. Otherwise, team performance can be jeopardized and potential risks can be overlooked, causing serious problems during project execution. Besides, the statistical analysis shows that the scale is very consistent and has a strong correlation with the constructs. Finally, a parsimonious model was delivered, as needless complexity was cut away and the model was reduced 


\section{IT Project Manager Competencies and Team Commitment: A New Scale Proposal}

as much possible (Vandekerckhove, Matzke, \& Wagenmakers, 2015).

This study also provides foundation for further studies. It offers consistent material for scholars to develop researches regarding the influence of team commitment and project manager competencies on IT project success. A limitation of this study is not measuring the relevance of project manager competencies according to project phase or culture demands of the setting project managers are inserted in (Ahadzie, Proverbs, \& Sarkodie-Poku, 2014). An interesting idea for future studies is to assess the model derived from the statistical analysis empirically.

\section{REFERENCES}

Allen, N. J., \& Meyer, J. P. (1990). The measurement and antecedents of affective, continuance and normative commitment to the organization. Journal of Occupational Psychology, 63(1), 1-18.

Araújo, C. C. S. \& Pedron, C. D. (2015). IT project manager competencies and IT project success: a qualitative study. Organisational Project Management, 2(1), 53-75.

Araújo, C. C. S. \& Pedron, C. D. (2016). A importância dos soft skills e o tipo de personalidade dos gerentes de projetos de TI. International Journal of Professional Business Review, 1(1), 40-59.

Araújo, C. C. S., Modolo, D., Carneiro Jr., E., \& Vils, L. (2017). Análise da relação entre clima organizacional e o desempenho criativo em organizações brasileiras. NAVUS - Revista de Gestãoe \& Tecnologia, 7(2), 97-112.

Ahadzie, D. K., Proverbs, D. G. and Sarkodie-Poku, I. (2014). Competencies required of project managers at the design phase of mass house building projects. International Journal of Project Management, 32(6), 958-969.

Beavers, A. S., Lounsbury, J. W., Richards, J. K., Huck, S. W., Skolits, G. J., \& Esquivel, S. L. (2013). Practical considerations for using exploratory factor analysis in educational research. Practical Assessment, Research \& Evaluation, 18(6), 1-13.

Bishop, J. W., \& Scott, K. D (2000). An examination of organizational and team commitment in a self- directed team environment. Journal of Applied Psychology, 85(3), 439-450.

Bishop, J. W., Scott, K. D., \& Burroughs, S. M. (2000). Support, commitment and employees outcomes in a team environment. Journal of Management, 26(6), 1113-1132.

Brière, S., Proulx, D., Flores, O. N., \& Laporte, M. (2015). Competencies of project managers in international NGOs: Perceptions of practitioners. International Journal of Project Management, 33(1), 116-125.

Churchill, G. A. (1979). A paradigm for developing better measures of marketing constructs. Journal of Marketing Research, 16(1).

Crawford, L. (2005). Senior management perceptions of project management competence', International Journal of Project Management, 23(2005), 7-16.

Creswell, J. W., \& Plano-Clark, V. L. (2011). Designing and Conducting Mixed Methods Research 2nd Edition. Thousand Oaks: SAGE Publications, Inc.

Damatta, R. (1991). Carnivals, Rogues and Heroes: An Interpretation of the Brazilian Dilemma (Translated by John Drury). University of Notre Dame Press.

DeVellis, R. F. (2003). Scale Development - Theory and Applications 2nd edition (2nd ed., Vol. 26). Thousand Oaks: SAGE Publications, Inc.

Fornell, C., \& Larcker, D. F. (1981). Structural equation models with unobservable variables and measurement error: Algebra and statistics. Journal of Marketing Research, 18(3), 328-388.

Gibbs, G. (2009). Análise de Dados Qualitativos. (U. Flick, Ed.) (p. 198). Porto Alegre: Atmed Editora S.A.

Guadagnoli, E., \& Velicer, W. F. (1988). Relation to sample size to the stability of component patterns. Psychological Bulletin, 103(2), 265-275.

Hilal, A. (2003). Organizational Culture Dimensions: A Brazilian Case. In Encontro da ANPAD ENANPAD (pp. 1-15). Atibaia, SP, Brazil: ANPAD.

Henseler, J., Ringle, C. M. \& Sinkovics, R. R. (2009). The use of partial least squares path modeling in international marketing', in Sinkovics, R. R. and 


\section{IT Project Manager Competencies and Team Commitment: A New Scale Proposal}

Ghauri, P. N. (eds) Advances in International Marketing. Bingley: Emerald Group Publishing Limited (Advances in International Marketing), 277319.

Hofstede, G., Hofstede, G. J., \& Minkov, M. (2010). Cultures and Organizations - Intercultural Cooperation and Its Importance for Survival (3 rd). New York: The McGraw-Hill Companies Inc.

Hinkin, T. R. (1998). A Brief Tutorial on the Development of Measures for Use in Survey Questionnaires. Organizational Research Methods, 1(1), 104-121.

Jha, K. N., \& Iyer, K. C. (2007). Commitment, coordination, competence and the iron triangle. International Journal of Project Management, 25(5), 527-540.

Keil, M., Lee, H. K., \& Deng, T. (2013). Understanding the most critical skills for managing IT projects: A Delphi study of IT project managers. Information \& Management, 50(7), 398-414.

Kerzner, H. (2009). Project Management: A Systems Approach to Planning, Schedulling and Controlling (10th). New Jersey: John Wiley \& Sons, Inc.

Korzaan, M. L. (2009). The Influence of Commitment to Project Objectives in Information Technology (IT) Projects. Review of Business Information Systems, 13(4), 89-98.

Leung, M., Chen, D., \& Yu, J. (2008). Demystifying moderate variables of the interrelationships among affective commitment, job performance, and job satisfaction of construction professionals. Journal of Construction Engineering and Management, 134(12), 963-971.

Mathisen, G. E., Einarsen, S., \& Mykletun, R. (2012). Creative leaders promote creative organizations. International Journal of Manpower, 33(4), 367-382.

Mowday, R. T., Steers, R. M., \& Porter, L. W. (1979). The measurement of organizational commitment. Journal of Vocational Behavior, 14(2), 224-247.

Moraes, F. M. M., Godoi, C. K., \& Batista, M. A. (2004). Comprometimento organizacional: Sobre a produção científica brasileira de 1994 a 2003. Revista de Ciências da Administração, v. 6, n. 12, 1-19.
Müller, R., \& Turner, R. (2010). Leadership competency profiles of successful project managers. International Journal of Project Management, 28(5), 437-448.

PMI. (2013). A Guide to the Project Management Body of Knowledge (PMBOK® Guide) (5th ed.). Pennsylvania: Project Management Institute, Inc.

Porter, L. W., Crampon, W. J., \& Smith, F. J. (1972). Organizational commitment and managerial turnover: A longitudinal study. Irvine, California, USA. Retrieved from http://oai.dtic.mil/oai/oai?verb=getRecord\&metadata Prefix $=$ html\&identifier $=$ AD0751082

Rigo, G.-E., Pedron, C. D., Caldeira, M., \& Araújo, C. C. S. de. (2016). CRM Adoption in a Higher Education Institution. Journal of Information Systems and Technology Management, 13(1), 45-60.

Ringle, C. M., Silva, D., \& Bido, D. (2014). Structural equation modeling with the SMARTPLS, Revista Brasileira de Marketing - REMARK, 13(2), 56-73.

Sabherwal, R., \& Elam, J. (1995). Overcoming the problems in information systems development by building and sustaining commitment. Accounting, Management and Information Technologies, 5(3-4), 283-309.

Shenhar, A. J., \& Dvir, D. (2007). Reinventing Project Management - The Diamond Approach to successful growth and innovation. USA: Harvard Business School Press.

Skulmoski, G. J., \& Hartman, F. T. (2009). Information systems project manager soft competencies: A project-phase investigation. Project Management Journal, 41(1), 61-80.

Slavec, A., \& Drnovesek, M. (2012). A perspective on scale development in entrepreneurship research. Economic and Business Review, 14(1), 39-62.

Stevenson, D. H., \& Starkweather, J. A. (2010). PM critical competency index: IT execs prefer soft skills. International Journal of Project Management, 28(7), 663-671. .

Sumner, M., Bock, D., \& Giamartino, G. (2006). Exploring the linkage between the characteristics of IT project leaders and project success. Information Systems Management, 23(4), 43-49. 
Takey, S. M., \& Carvalho, M. M. (2015). Competency mapping in project management: An action research study in an engineering company. International Journal of Project Management, 33(4), 784-796.

Thamhain, H. J. (2004). Team leadership effectiveness in technology-based project environments. Project Management Journal, (December), 35-47.

Thamhain, H. J. (2011). Critical Success Factors for Managing Technology - Intensive Teams in the Global Enterprise, 23(3) Engineering Management Journal, 23(3), 30-36.

Thamhain, H. J. (2013). Building a Collaborative Climate for Multinational Projects. Procedia - Social and Behavioral Sciences, 74, 21-33.

The Standish Group. (2013). The Chaos Manifesto 2013 - Think Big, Act Small. Boston. The Standish Group. (2014). Big Bang Boom (pp. 1-52).

Turner, J. R., \& Müller, R. (2005). The project manager's leadership style as a success factor on projects: a literature review. Project Management Journal, 36(2), 49-61.
Vandekerckhove, J., Matzke, D., \& Wagenmakers, E. J. (2015). Model Comparison and the Principle of Parsimony. In J. Busemeyer, J. Townsend, Z. J. Wang, \& A. Eidels (Eds.), Oxford Handbook of Computational and Mathematical Psychology. Oxford: Oxford University Press.

Wateridge, J. (1997). Training for IS/IT project managers: a way forward. International Journal of Project Management, 15(5), 283-288.

Williams, B., Onsman, A., \& Brown, T. (2010). Exploratory factor analysis: A five-step guide for novices. Journal of Emergency Primary Health Care (JEPHC), 8(3), pp. 1-13.

Xu, X., Zhang, W., \& Barkhi, R. (2010). IT infrastructure capabilities and IT project success: a development team perspective. Information Technology and Management, 11(3), 123-142.

Zambaldi, F., Costa, F. J., \& Ponchio, M. C. (2014). Measurement in Marketing: Current Scenario, Recommendations and Challenges. Brazilian Journal of Marketing (BJM), 13(2), 1-27. 


\section{IT Project Manager Competencies and Team Commitment: A New Scale Proposal}

Appendix 1 - Items used in the online survey (in Portuguese)

\begin{tabular}{|c|c|}
\hline Indicators & Survey Items in Portuguese (regarding Team Commitment) \\
\hline TC1 & Acham ótimo trabalhar com seus companheiros de equipe. \\
\hline TC2 & Aceitam executar praticamente qualquer tarefa a fim de permanecer na equipe em que trabalham. \\
\hline TC3 & Acreditam que os seus valores pessoais estão alinhados com os valores da equipe em que trabalham. \\
\hline TC4 & Sentem orgulho de fazerem parte da equipe em que trabalham. \\
\hline TC5 & Se sentem motivados a dar o seu melhor pelo bem da equipe. \\
\hline TC6 & Se sentem felizes por integrarem a equipe em que trabalham atualmente. \\
\hline TC7 & Se importam verdadeiramente com o que acontece com a equipe em que trabalham. \\
\hline TC8 & Acreditam que a equipe em que trabalham é a melhor para se trabalhar. \\
\hline TM1 & Lideram a equipe, sem serem autoritários(as), para que esta cumpra os objetivos do projeto com entusiasmo. \\
\hline TM2 & Se engajam de forma espontânea para cumprir tarefas. \\
\hline TM3 & Entendem as funções de cada equipe e onde estas funções se intercalam. \\
\hline TM4 & $\begin{array}{l}\text { Sabem lidar com fatores interculturais como diferença de fusos horários, costumes internacionais, feriados, } \\
\text { tradições e éticas de trabalho distintas. }\end{array}$ \\
\hline TM5 & Compartilham informações sobre o projeto com todos os envolvidos. \\
\hline TM6 & Compartilham os créditos pelo sucesso do projeto com sua equipe. \\
\hline TM7 & Dão feedback positivo ou negativo aos membros da equipe em tempo oportuno. \\
\hline TM8 & Delegam poderes e responsabilidades aos membros da equipe (empowerment). \\
\hline BDK1 & $\begin{array}{l}\text { Entendem os requisitos de negócio bem como os fatores que podem afetar a saúde do projeto, em vez de } \\
\text { apenas focar na solução técnica. }\end{array}$ \\
\hline BDK2 & Identificam quais indivíduos (stakeholders) serão impactados pelo projeto. \\
\hline BDK3 & Vendem o projeto para os usuários finais, fazendo com eles aceitem o sistema. \\
\hline BDK4 & Entendem o que é o produto final, como o produto final funciona e que objetivo este produto deve cumprir. \\
\hline BDK5 & Documentam os processos organizacionais com efetividade. \\
\hline BDK6 & Veem o panorama geral e tomam decisões táticas/estratégicas que beneficiam o projeto. \\
\hline BDK7 & Entendem as diferenças culturais na organização e sabem como lidar com as "regras não escritas". \\
\hline COMM1 & Comunicam-se bem tanto de forma verbal como escrita com todos os envolvidos no projeto. \\
\hline COMM2 & Sabem como convencer as pessoas a seguir uma direção em vez de outra. \\
\hline COMM3 & $\begin{array}{l}\text { Comunicam-se abertamente no intuito de aumentar a confiança e melhorar a comunicação em todas as fases } \\
\text { do projeto. }\end{array}$ \\
\hline COMM4 & $\begin{array}{l}\text { Comunicam-se não somente com os membros do seu time, mas também com stakeholders e com pessoas de } \\
\text { diferentes níveis de hierarquia. }\end{array}$ \\
\hline COMM5 & Escutam atenciosamente os membros do seu time. \\
\hline PM1 & Gerenciam bem o escopo do projeto. \\
\hline PM2 & $\begin{array}{l}\text { A partir dos requisitos de negócio, criam atividades e prazos precisos, prevendo penalidades pelo não } \\
\text { cumprimento destes. }\end{array}$ \\
\hline PM3 & $\begin{array}{l}\text { Gerenciam bem o tempo a fim de evitar gargalos, utilizando técnicas adequadas como por exemplo análise } \\
\text { de caminho crítico. }\end{array}$ \\
\hline PM4 & Controlam bem o orçamento do projeto e seus custos reais. \\
\hline PM5 & Identificam potenciais riscos e desenvolvem planos para reduzir ou eliminar estes riscos. \\
\hline PM6 & Identificam e expandem oportunidades de melhoria e de crescimento. \\
\hline PS1 & Gerenciam conflitos construtivamente de modo a obter alinhamento entre os envolvidos no projeto. \\
\hline PS2 & Sabem satisfazer as motivações do pessoal de negócios e da área técnica. \\
\hline PS3 & Sabem discernir e lidar com questões políticas. \\
\hline PS4 & Sabem trabalhar e interagir com todos os tipos de pessoas em todos os tipos de situações. \\
\hline PS5 & $\begin{array}{l}\text { Constroem relacionamentos e sabem negociar com os diferentes envolvidos dos distintos níveis hierárquicos } \\
\text { (área técnica e área de negócio). }\end{array}$ \\
\hline PROF1 & Cumprem suas promessas e demostram alto nível de ética. \\
\hline PROF2 & Participam e contribuem plenamente. \\
\hline PROF3 & Executar suas tarefas com responsabilidade. \\
\hline PROF4 & São comprometidos com o projeto. \\
\hline PROF5 & Sabem como aprender a partir de experiências anteriores e de interações com outros profissionais. \\
\hline
\end{tabular}


IT Project Manager Competencies and Team Commitment: A New Scale Proposal

PCH1 $\quad$ Ajudam outras pessoas, a fim de alcançar um objetivo em comum.

PCH2 Sabem se colocar no lugar do outro para saber como o outro se sente (empatia).

PCH3 Tomam decisões baseadas em fatos reais em vez de sentimentos ou crenças pessoais.

PCH4 Têm iniciativa e pró-atividade.

PCH5 São pessoas organizadas.

PCH6 São transparentes e honestos. 
Appendix 2 - Scale used in the online survey (in English).

\begin{tabular}{|c|c|c|c|}
\hline $\begin{array}{l}\text { Construct/ } \\
\text { Competence }\end{array}$ & Indicators & Competence element & Scale Item \\
\hline \multirow{8}{*}{$\begin{array}{c}\text { Team } \\
\text { Commitment }\end{array}$} & TC1 & \multirow{8}{*}{ Not applicable } & Think it is great working with team mates \\
\hline & TC2 & & Accept doing almost any task to remain in the team they are working with. \\
\hline & TC3 & & Believe that their personal values are aligned with the values of the team they are working with. \\
\hline & TC4 & & Feel proud to be part of the team they are in. \\
\hline & TC5 & & Feel motivated to give their best for the welfare of the team. \\
\hline & TC6 & & Feel happy to be part of the team they are currently in. \\
\hline & TC7 & & Indeed care about what happens to their team. \\
\hline & TC8 & & Believe that the team they are in is the best place to work. \\
\hline \multirow{8}{*}{$\begin{array}{c}\text { Team } \\
\text { management }\end{array}$} & TM1 & $\begin{array}{l}\text { Ability to motivate team } \\
\text { members }\end{array}$ & Lead the team, without being authoritarian, so that the team accomplishes the project goals with enthusiasm. \\
\hline & TM2 & Collaboration & Engage themselves to accomplish tasks spontaneously. \\
\hline & TM3 & $\begin{array}{l}\text { Ability to bridge diverse } \\
\text { teams }\end{array}$ & Have a good understanding of each team's responsibilities and where they overlap. \\
\hline & TM4 & Virtual team skills & $\begin{array}{l}\text { Know how to deal with cross-cultural factors such as different time zones, international customs, holidays, } \\
\text { traditions and distinct work ethics. }\end{array}$ \\
\hline & TM5 & Share information & Share information about the project with all people involved. \\
\hline & TM6 & Share credit & Share credit for project success with their team. \\
\hline & TM7 & Provide feedback & Give team members timely positive or negative feedback. \\
\hline & TM8 & $\begin{array}{l}\text { Give autonomy to team } \\
\text { members }\end{array}$ & Delegate power and responsibilities to team members (empowerment). \\
\hline \multirow{7}{*}{$\begin{array}{l}\text { Business domain } \\
\text { knowledge }\end{array}$} & BDK1 & $\begin{array}{l}\text { Ability to understand the } \\
\text { business domain }\end{array}$ & $\begin{array}{l}\text { Understand the business requirements as well as the factors that can affect the project's health, instead of only } \\
\text { focusing on the technical solution. }\end{array}$ \\
\hline & BDK2 & $\begin{array}{l}\text { Ability to identify } \\
\text { stakeholders }\end{array}$ & Identify the individuals (stakeholders) that will be impacted by the project. \\
\hline & BDK3 & Ability to involve end-users & Sell the project to end-users and make them accept the system. \\
\hline & BDK4 & $\begin{array}{l}\text { Knowledge of the end } \\
\text { product }\end{array}$ & Understand what the end product is, how it works and what it must accomplish. \\
\hline & BDK5 & Ability to document process & Document organizational processes effectively. \\
\hline & BDK6 & Strategic thinking & See the big picture and make tactical/strategic decisions that benefit the project. \\
\hline & BDK7 & Cultural fit & Understand the cultural differences within the organization and know how to deal with the "unwritten guidelines". \\
\hline \multirow{3}{*}{ Communication } & COMM1 & Communication & Have both verbal and written skills to communicate well with all those involved in the project. \\
\hline & COMM2 & $\begin{array}{l}\text { Ability to construct } \\
\text { persuasive arguments }\end{array}$ & Know how to persuade people to follow one direction rather than the other \\
\hline & COMM3 & Open communication & Communicate openly in order to build trust and improve communication in all project phases. \\
\hline
\end{tabular}

ARAÚJO/ PEDRON

QUEVEDO-SILVA
Revista de Gestão e Projetos - GeP

Vol. 9, N. 1. Janeiro/Abril. 2018 


\begin{tabular}{|c|c|c|c|}
\hline $\begin{array}{l}\text { Construct/ } \\
\text { Competence }\end{array}$ & Indicators & Competence element & Scale Item \\
\hline & COMM4 & $\begin{array}{l}\text { Ability to communicate at } \\
\text { multiple levels }\end{array}$ & $\begin{array}{l}\text { Are able to communicate not only with his/her team members but also with stakeholders and people from } \\
\text { different hierarchical levels. }\end{array}$ \\
\hline & COMM5 & Listening & Listen closely to his/her team members. \\
\hline \multirow{6}{*}{$\begin{array}{c}\text { Project } \\
\text { management }\end{array}$} & PM1 & Scope management & Manage the project scope well. \\
\hline & PM2 & Project planning & $\begin{array}{l}\text { With business requirements as a starting point, create activities and precise deadlines, avoiding penalties for not } \\
\text { meeting these deadlines. }\end{array}$ \\
\hline & PM3 & Time management & $\begin{array}{l}\text { Make a good time management to prevent bottlenecks, by using appropriate techniques such as critical path } \\
\text { analysis. }\end{array}$ \\
\hline & PM4 & Cost management & Have good control of project budget and its actual costs. \\
\hline & PM5 & Risk management & Identify potential risks and develop a plan to reduce or eliminate these risks. \\
\hline & PM6 & Identify/expand opportunities & Identify and expand opportunities for improvement and growth. \\
\hline \multirow{5}{*}{ People skills } & PS1 & Conflict management & Manage conflicts constructively to obtain alignment within those involved in the project. \\
\hline & PS2 & $\begin{array}{l}\text { Understanding the } \\
\text { psychology of people }\end{array}$ & Know how to satisfy the motivations of the business and technical personnel. \\
\hline & PS3 & $\begin{array}{c}\text { Political awareness/agility/ } \\
\text { tact }\end{array}$ & Discern and deal with political issues. \\
\hline & PS4 & Good people skills & Work with and interact with all types of people in all types of situations. \\
\hline & PS5 & Negotiation & $\begin{array}{l}\text { Build relationships and are able to negotiate with the different people involved at distinct hierarchical levels } \\
\text { (technical and business area). }\end{array}$ \\
\hline \multirow{5}{*}{ Professionalism } & PROF1 & Credibility & Keep their promises and demonstrate a high level of ethics. \\
\hline & PROF2 & $\begin{array}{l}\text { Participate and contribute } \\
\text { fully }\end{array}$ & Participate and contribute fully. \\
\hline & PROF3 & Ownership of tasks & Are accountable for their tasks. \\
\hline & PROF4 & Commitment & Are committed to the project. \\
\hline & PROF5 & Experience & Know how to learn from past experiences and interaction with others professionals. \\
\hline \multirow{6}{*}{$\begin{array}{c}\text { Personal } \\
\text { characteristics }\end{array}$} & PCH1 & Cooperation & Help others for the common benefit. \\
\hline & $\mathrm{PCH} 2$ & Empathy & Know how to put themselves in the place of another to feel what another feels (empathy). \\
\hline & $\mathrm{PCH} 3$ & Decisiveness & Take decisions based on real facts instead of feelings or personal beliefs. \\
\hline & PCH4 & Initiative-proactive & Have initiative and pro-activity. \\
\hline & PCH5 & $\begin{array}{l}\text { Self-organization/self- } \\
\text { directed }\end{array}$ & Are organized people. \\
\hline & PCH6 & Transparency-honesty & Are transparent and honest. \\
\hline
\end{tabular}

